\title{
Medya ve Nihilizm: Türk Medyası Örneği ${ }^{\star}$
}

\author{
Pınar Basmacı (Arş. Gör.)
}

Marmara Üniversitesi İletişim Fakültesi

pinarkovaci@gmail.com

Bașvuru Tarihi: 25.03.2020

Yayına Kabul Tarihi: 08.07.2020

Yayınlanma Tarihi: 24.07.2020

https://doi.org/10.17680/erciyesiletisim.709051

\section{Öz}

Hiççilik kelimesine karşılık gelen nihilizm, öz ile değer ve amaç yoksunluğudur. Yanılsama felsefesi olarak da nitelendirilen nihilizm, Nietzsche tarafından aktif ve pasif olarak sınıflandırılmakta, Baudrillard tarafindan da buna saydam nihilizm eklenmektedir. Bununla birlikte politik, ahlaki, epistemolojik, kozmik ve varoluşsal olarak da ayrılan nihilizm, medyayla çok daha farklı anlamlara bürünmektedir. Medyanın rollerinin dönüşmesi, eğlenceyi merkezine alması ya da olayları abartması medyadaki nihilizm olarak nitelendirilirken, nihilizm çeşitleri için de farklı tanımlamalar ortaya konmaktadır. Nihilizm ve nihilizm çeşitlerinin tablolaştırıldığı ve bu tabloda her nihilizm türüne ait parametrelerin belirlendiği çalışmada, söz konusu parametreler, medya ve nihilizm kapsamında belirlenmiştir. $\mathrm{Bu}$ noktadan hareketle, medya ve nihilizm arasındaki bağlantının, başka bir deyişle, medyadaki nihilizmin ele alındığı çalışmada, medyadaki nihilizmin nasıl olduğu ortaya koymak çalışmanın problemini; medyada nihilizmin olup olmadığının tespit edilmesi ise çalışmanın amacını oluşturmaktadır. Bu bağlamda tüm medyayı temsil edebilmesi için gazete haberinden, televizyon haberinden, sosyal medya paylaşımlarından, televizyon gündüz kuşağı programlarından, dizi ve sinema filmlerinden birer örneklemin alındığı çalışmada, amaçsal örnekleme metodu kullanılmış olup, örnekler söylem analizi yöntemi kullanarak çözümlenmiştir. Çalışmanın sonucunda bütün medya metinlerinin nihilistik önermeler sunarak, izleyicileri de nihilizme doğru sürüklediği sonucuna ulaşılmıștır.

Anahtar Kelimeler: Radyo Televizyon ve Sinema, Nihilizm, Nihilizm Türleri, Nietzsche ve Medya.

\footnotetext{
* Bu çalışma, Marmara Üniversitesi Sosyal Bilimler Enstitüsü’ne sunulmak için hazırlanan ve henüz savunulmamış “Medya ve Nihilizm: Türk Medyası Örneği” başlıklı doktora tez özetidir.
} 


\title{
Media and Nihism: Turkish Media Example
}

\author{
Pınar Basmacı (Res. Asst.) \\ iD Marmara University Faculty of Communication
} pinarkovaci@gmail.com

Date Received: 25.03.2020

Date Accepted: 08.07.2020

Date Published: 24.07.2020

https://doi.org/10.17680/erciyesiletisim.709051

\begin{abstract}
Nihilism, which corresponds to the word "nothingness", is the lack of essence and value and purpose. Qualified as the philosophy of illusion, nihilism is classified as active and passive by Nietzsche, and transparent nihilism is added to it by Baudrillard. However, nihilism, which is divided into political, moral, epistemological, cosmic and existentially, has much different meanings with the media. Transformation of the roles of the media, centering the entertainment or exaggerating the events are described as media nihilism, while different definitions are presented for the types of nihilism. In the study where the types of nihilism and nihilism are tabulated and the parameters of each type of nihilism are determined in this table, the parameters in question were determined within the scope of media and nihilism. From this point on, in the study where the connection between media and nihilism, in other words, nihilism in the media, the problem of the study is to reveal how nihilism in the media is; The purpose of the study is to determine whether there is nihilism in the media. In this context, a purposeful sampling method was used in the study, in which a sample was taken from newspaper news, television news, social media posts, television daytime programs, series and cinema films, and samples were analyzed using discourse analysis method. As a result of the study, it has been concluded that all media texts offer nihilistic propositions and drag the audience towards nihilism.
\end{abstract}

Keywords: Radio Television and Cinema, Nihilism, Types Of Nihilism, Nietzsche and Media. 


\section{Giriş}

Nihilizmin gelişini haber vererek, bunun bir felaket olacağını söyleyen Nietzsche, hiçlik istenci, yanılsama felsefesi gibi nihilizm tanımlamaları yapmaktadır. Nihilizm tecrübesinin bir yazgı olduğunu söyleyen Nietzsche, nihilizmi aktif ve pasif olarak ikiye ayırmaktadır. Modern düşünür Nietzsche'den farklı olarak, postmodern düşünür Baudrillard ise farklı bir nihilizm tanımlaması getirmektedir. Bu bağlamda Baudrillard, postmodern süreçte nihilizmin yerini artık saydam nihilizmin aldığını ifade etmekte ve bu nihilizm türü, Weller tarafından postmodern nihilizm olarak nitelendirilmektedir. Bunların yanı sıra politik, ahlaki, epistemolojik, kozmik ve varoluşsal nihilizm türlerinden de bahsedilmektedir.

Birçok alanda kendini gösteren nihilizm, medyada da varlığını ortaya koymaktadır. Ancak medya içerisinde, kriz ve başarısızlık söylemi, olayları abartma, keder ve korku salma gibi nihilizm tanımlamaları bulunmaktadır. Daha açık bir deyişle, medya sahip olduğu anlam yaratma ve yönlendirme gücüyle nihilistik önermeler üretmekte ve bunları medya metinleriyle yaymaktadır. Fakat bu noktada, klasik nihilizm tanımlamalarından farklı nihilizm tanımlamaları ortaya konmaktadır. Bu perspektifle çalışmada, nihilizm türlerinin ve bu türlere ait parametrelerin sunulduğu bir tablo ortaya konmuştur. Başka bir deyişle, her nihilizm türü için medya bağlamında parametreler belirlenmiş ve o parametrelerden bir veya daha fazlası görüldügünde, söz konusu nihilizm türünün olduğu iddia edilmiştir.

Bu bağlamda, medya ve nihilizm ilișkisinin ele alındığı çalışmada, medya ve nihilizm arasında nasıl bir ilişki olduğunu bulmak çalışmanın problemini; medyada nihilizmin olup olmadığını tespit etmek ise amacını oluşturmaktadır. Söz konusu ilişkiyi ortaya koyabilmek adına da tüm medya alanlarından birer örnek alınmıştır. Toplamda yedi örneğin analiz edildiği çalışmada, amaçsal örnekleme metodu ile söylem analizi yöntemi kullanılmıştır.

$\mathrm{Bu}$ doğrultuda öncelikle nihilizm konusunun ele alındığı çalışmada nihilizmin ne olduğundan ve nihilizm türlerinden bahsedilecektir. Ardından medya ve nihilizm ilişkisi kuramsal anlamda irdelenecektir. Son olarak da örnek olarak alınan medya metinleri, oluşturulan tabloya göre analiz edilecek ve çıkan sonuçlar da sonuç bölümünde tartışlacaktır.

\section{Nihilizm}

Türkçe "Hiççilik" kelimesine karşılık gelen nihilizmin gelişimiyle ilgili Nietzsche şunları söylemektedir: "Burada gözler önüne sermeye çalıştığım, gelecek iki yüzyıldır. Gelecek olanı tarif ediyorum, artıkfarklı gelemeyecek olant: Nihilizmin gelişini... Bu gelecek daha şimdiden yüzlerce işaretle konuşmaktadır; bu kader kendini her yerde ilan etmektedir. Geleceğin bu müziği için tüm kulaklar daha şimdiden dikildi. Tüm Avrupa kültürü, ne zamandır her on yılda bir işkenceler içinde büyüyen bir gerilimle bir felakete doğru sürüklenmektedir: Dur durak bilmeksizin, şiddetle, düşünmeksizin, tıpkı sona varmak isteyen, artık düşünmeyen, düşünmekten korkan bir nehir gibi" (Nietzsche, 2010, s. 21). Bu perspektifle, Nietzsche'nin nihilizmin gelişini kaçınılmaz olarak gördüğünü söylemek mümkündür. Geleceğin yüzlerce işaretinin olduğunu ifade eden Nietzsche, bununla nihilizmin gelişinin işaretlerinden bahsetmekte ve nihilizmin gelişinin Avrupa'yı felakete sürükleyeceğini söylemektedir.

Nihilizm üzerine birçok şey söyleyen Nietzsche, nihilizm ile ilgili çeşitli tanımlamalar da yapmaktadır. Bunlardan en bilineni en yüksek değerlerin, değerlerini kaybetmesi tanımlamasıdır (Nietzsche, 2010, s. 27). Bununla birlikte, Nietzsche nihilizmin, insanın, bir istem konusu olan değer ve amaçlardan yoksun kalınca hiçliği istemesi olduğunu da 
söylemektedir (Nietzsche, 2000, s. 51). Ancak "boşuna" olanın üzerine düşünmek ya da her şeyin yok olmayı hak ettiğine dair bir inanç olmadığını da eklemektedir (Nietzsche, 2010, s. 38). Kudret Iradesi kitabında ise nihilizmi şu şekilde tanımlamaktadır: Nihilizm gaye yokluğu ve niçin sorusunun cevapsız kalmasıdır. Nihilizm aktif olarak şiddetli bir tahrip gücüyle azami kuvvet derecesine varmaktadır. Bugün ise bu nihilizmin zıddı, hiçbir şeye hücum etmeyen yorgun nihilizm söz konusudur (Safa, 2005, s. 284). İyinin ve Kötünün Ötesinde kitabında nihilizmi, umudu kesik ve yorgun bir ruhun işareti olarak tanımlamaktadır (Nietzsche, 2001, s. 7). Fakat genel olarak bütün tanımlamalarındaki ortak noktalar, değer ve amaçların yoksunluğu, hiçliği isteme ve niçin sorusunun cevapsız kalmasıdır.

Nietzsche nihilizm ile ilgili ayrışmaya gitmekte ve nihilizm çeşitlerinden bahsetmektedir. Söz konusu nihilizm çeşitlerini anlatmak çalışmaya sağlayacağı yarar bakımından önemlidir. Nietzsche temelde nihilizmi orijinal ve Avrupa nihilizmi olarak ikiye ayırmaktadır. Bu noktadan hareketle şunları söylemek mümkündür: Nietzsche için nihilizm insandan çıkan, ancak daha sonra iki farklı kanaldan akan bir kavramdır. Söz konusu kaynaklar, Platonculuktan başlayarak, tüm Batı düşüncesini içerisine alan metafizik tarihidir ve bu tarih orijinal nihilizm olarak adlandırılmaktadır. Diğeri ise, bu içeriğin sonucu olarak gelinen noktanın farklı bakış açıları ile nasıl yorumlandığını ortaya koymakta ve bu da Avrupa nihilizmi olarak adlandırılmaktadır (Mengü, 2006, s. 40).

Orijinal ve Avrupa nihilizminin yanı sıra nihilizmin, bir yanılsama felsefesi, daha açık bir deyişle dünyayı olduğu gibi kabullenmeme durumu olduğu ve bu bağlamda aktif ve pasif nihilizm de yanılsama dağıldığında, yani Tanrı öldüğünde ortaya çıkan nihilizm biçimleri olduğunu söylemektedir. Başka bir deyişle, Tanrı'nın ölümünün iki yönü vardır: Yönünü kaybetme, yani pasif nihilizm ve umutsuzluk, yani aktif nihilizm (Diken, 2011, s. 45). Bu doğrultuda Nietzsche, radikal ve etkin nihilizm olarak da adlandırılan aktif nihilizmi, ruhun artan gücünün işareti olarak ve edilgin olarak da adlandırılan pasif nihilizmi de ruhun gücünün azalması ve gerilemesi olarak tanımlamaktadır (Nietzsche, 2010, s. 37-38). Nietzsche'ye göre aktif nihilizm, nispi gücün en üst noktasına şiddetli bir yok etme gücü olarak ulaşırken; bunun karşısında olan pasif nihilizm ise saldırmayan, bitkin ve bu bağlamda da zayıf nihilizmdir. Pasif nihilizme göre yanlış olan değerlerdir, dünyanın kendisi değil; fakat aktif nihilizme göre ise sorun değerlerde değil, dünyanın kendisindedir. Pasif nihilizmde değerlerin bulunmadığı bir dünya, aktif nihilizmde ise dünyası olmayan değerler söz konusudur (Diken, 2011, s. 45-46). Daha öz bir deyişle iki yönü bulunan nihilizmin saldırmayan, bitkin tarafı pasif; yıkıcı tarafı ise aktif nihilizm olarak adlandırılmaktadır. Bu noktadan hareketle değerlerin yıkımından bahseden Nietzsche'nin de aktif bir nihilist olduğunu söylemek mümkündür.

Öte yandan modern felsefenin düşünürü Nietzsche, modernizme olan eleștirileriyle postmodern felsefenin temelini atmış ve nihilizmi, modernizme bir başkaldırı olarak nitelendirdiği için, modernizm karşıtı olan postmodernizm de nihilist kabul edilmiştir. Daha açlk bir deyişle, modernizme tepki olarak ortaya çıkan postmodernizmin, belli bir tanımı bulunmasa da zaman dilimi olarak 1950'lerden sonrasına işaret etmektedir. Postmodernizmin, modernizmin karşısında durmasından dolayı modernizme karşı olan nihilizmle özdeș görülerek, nihilist olduğu ifade edilmektedir. Bu bağlamda, postmodernitedeki nihilizm de moderntideki nihilizmden farklı bir yerde durmakta ve postmodern düşünür Baudrillard tarafından saydam nihilizm kavramı ortaya atılmaktadır. Baudrillard'a göre nihilizmin, artık Tanrı'nın ölümü ile birlikte ortaya çıkan çöküşle ilgisi kalmamıştır. Günümüzde olsa olsa saydamlaşmış bir nihilizmden bahsedilmektedir. 
Ancak söz konusu bu nihilizm, kendinden önceki nihilizmlerden çok daha acımasız ve radikaldir. Bunun nedeni ise saydamlık ve boşlukta yüzer gibi olma halinin hem sistem hem de onu çözümlediğini iddia eden tüm kurumların ayrılmaz bir parçasına dönüşmüş olmasıdır (Baudrillard, 2011, s. 214). Baudrillard'ın saydam nihilizmi, Weller tarafından postmodern nihilizm olarak da adlandırılmakta ve ikisi de artık mutlak gerçekliğin olmadığından, temsil sistemlerinin ise orijinali olmayan kopyalardan ibaret olduğundan ve bu bağlamda da simülasyon ve hipergerçeklik kavramlarının önem kazandığından bahsetmektedir.

Son olarak Crosby beş farklı nihilizm türünü ele almaktadır: Politik, ahlaki, epistemolojik, kozmik ve varoluşsal. Politik nihilizm, hiçbir otoriteye boyun eğmeme, herhangi bir prensibe sahip olmamadır. Politik nihilizm ahlaki nihilizm ile yakından ilişkilidir. Ahlaki nihilizmin üç biçimi söz konusudur: Bütün ahlâkî prensiplerin reddedilmesi, ahlaki yargıların keyfi olduğunun ve bu yargıları eleștirmenin mümkün olmadığının ifade edilmesi ve bireyin sadece kendisine karşı sorumlu olduğunun, bu yüzden de başkalarına karşı olan eylemlerinin sonuçları ile ilgili ahlaki bir endişe taşımaması gerektiğinin savunulması. Epistemolojik nihilizmin ise iki türünden bahsetmek mümkündür: Hakikatin bireylere ve gruplara bağlı olduğunun ifade edilmesi, bașka bir deyișle hakikate vurgu yapılması ve hakikatten ziyade anlamı odak noktasına alan nihilizmdir. Kozmik nihilizm, kozmosun anlamsızlığını ifade etmekle birlikte, bilinebilir bir yapının reddini ve insanın ihtiyacı olan değerlendirme biçimleri ile varoluşsal anlamları bulabileceği bir yerin var olabileceği düşüncesinin reddini de içermektedir. Son olarak varoluşsal nihilizm de anlam veya amacın olmadığı bir dünya üzerine temellenmekte ve böyle bir dünyada varoluşun kendisini boş bir şey olarak görmektedir (Crosby, 1998, s. 8-26).

$\mathrm{Bu}$ perspektifle politik nihilizm, siyasi bir amaç doğrultusunda hareket ederken; ahlaki nihilizm merkezine ahlakı; epistemolojik nihilizm de hakikati koymaktadır. Kozmik nihilizm ise varolușsal nihilizm ile eşdeğer bir durumdadır. $\mathrm{Bu}$ bağlamda varoluşsal nihilizmin, köktensizliği takip eden bir hiççilik duygusu olduğu söylenebilir (Özçınar, 2002, s. 86). Daha açık bir deyişle, varoluşta hiçbir şey yokmuş ve her şey boşunaymış gibi görünmekte ve bu boşuna kelimesi de bugünkü nihilizmin karakterini oluşturmaktadır. Varoluşun inkârı olan nihilizmin, düşünmenin kutsal bir yolu olabileceğini ifade etmektedir (Nietzsche, 2010, s. 34; 58). Başka bir ifadeyle varoluşçuluk özü itibari ile nihilizmi içinde barındırmaktadır.

\section{Medya ve Nihilizm}

Medyanın yapısı ve söz konusu bu yapının nihilizm ile ilişkisini ele almadan önce medya ve nihilizm üzerine yapılmış çalışmalara kısaca değinmek gerekmektedir. Bu noktadan hareketle şunları söylemek mümkündür: Medyanın geleneksel rollerinin hızla değişmiş ve haberlerin eğlenceye dönüşmüştür. Pritchard'ın ifadesi ile demokratik bir toplumda medyanın değișen rolüne "medya nihilizmi" denilmekte ve esasen bu kavram, medyanın kriz ve başarısızlık söylemi ile bir olayı abartma eğilimi olarak nitelendirilmektedir. Medya nihilizmi, başarısızlık beklentisi için toplumda ortak bir kültür yaratmakta ve kamuoyunu, krizin tüm yönleri ile ilgili bilgilendirmede başarısız olmaktadır. Hogan medya nihilizmini kriz ve başarısızlık söylemi olarak tanımlamaktadır. Fakat bu tanımlama genişletilerek, medya nihilizminin, bir olayı "görkemli" hale getirmek olduğu da söylenebilmektedir (Pritchard, 2010, s. 14).

Debord'dan aktarıldığı üzere medya nihilizminin önemli bir yönünü "yeniden birleşme” oluşturmaktadır. Yeniden birleşme, krizin bir kısmını veya tamamını, içinde bulunduğu 
orijinal bağlamdan ayırmak, orijinal bağlantılarının bir kısmını veya tamamını içermeyen başka bir bağlama yerleştirmek ve gerçekte krizin sahip olmadığı yetkiler veya nitelikler vermektir. Öz ile medya nihilizmi, hem gerçekliğin hem de toplumun krize ilișkin önemli konulardaki farkındalığında bir çarpıtma yaratmakta ve krizi parçalara ayırarak, bir noktasına odaklanmaktadır. Söz konusu odaklanma, genellikle olayı bir komplo olarak algılamakta ve onu bağlamından sıyırmaktadır. Ayrıca söz konusu medya nihilizmi, mantıksızlığı besleyerek, bireyleri gerçeklere ve mantığa karşı olumsuz duygular temelinde kararlar almaya zorlamaktadır (Pritchard, 2010, s. 4). Bu perspektifle bir olayı olduğundan daha olumsuz ya da olduğundan daha olumlu bir şekilde ortaya koymak medya nihilizmine işaret ettiği ifade edilebilir. Çünkü burada bir çarpıtma söz konusudur. $\mathrm{Bu}$ durum olayları bağlamından koparmayla özdeştir. Yeni bağlam içerisinde verilen olaylar, anlamın yok edilip, yeni anlam yüklenmesi nedeni ile nihilistiktir.

Devran ve Özcan'ın da ortaya koyduğu, medya nihilizminin gerçeklik ile toplumdaki önemli konulara ilişkin farkındalığın çarpıtılmasına dair söylemleri bunu desteklemektedir. Devran ve Özcan, medyanın abarttığı olayların çoğunlukla çözümsüz kaldığını söylemektedirler. Ayrıca buna, medya nihilizminin irrasyonaliteyi beslediğini de eklemektedirler (Devran \& Özcan, 2019, s. 192).

Nihilizm konusunu başka bir açısı ile ele alan Hibbs ise şunları söylemektedir: Eğer nihilizm hiçbir şey demekse, bu herhangi bir durumun gerçekliğini onaylamak için hiçbir temelin olmadığı, sadece tarihin ve deneyimin değişen zemini olduğu anlamındadır. Eğer nihilizmin klasik trajik ya da klasik olarak komik olma ihtimali yoksa sonraki aşama normal nihilizmdir. Nihilizm artık mücadele etmemekte ve benimsenmektedir. Bunun yerine, konuşulmayan bir varsayım haline gelmektedir. Sıradan nihilizmin nasıl olabileceği sitcom Seinfeld'da ortaya konmaktadır. Seinfeld "kesinlikle hiçbir şey" ile ilgili bir şovdur. Dizi Seinfeld karakterinin yaşamın nihai sonuçlarına veya temel amacına sahip olmayan bir dünyada yarattığı komik sonuçlara dairdir ve bu da Seinfeld'ın komik nihilizminin temelidir. Ayrıca, Seinfeld'ın mizahı sınırsızdır. Bu hem bir varsayım hem de onun nihilizminin bir sonucudur. Seinfield dünyanın herhangi bir nihai boşluğundaki önemin ya da temel anlamın komik sonuçları ile ilgili bir şovdur. Hibbs'in söylediklerinden hareketle, hiçbir şey ile ilgili olmayan, daha açık bir deyişle eğlence dışında hiçbir amacı, derdi olmayan, kültür endüstrisinin ürünü olmaktan öteye geçemeyen medya metinleri nihilizme işaret etmektedir (Hibbs, 2012, s. 6; 108-116).

Son olarak dijital iletişim teknolojileri ve nihilizm ilişkisine değinmek gerekmektedir. Lee internetin, bireylerin seçebileceği herhangi bir keyfi amaç için kullanılabileceği mutlak etkili araçların geliştirilmesiyle ilgili olduğunu söylemektedir. Bu yüzden interneti, bireylerin, anlam yaratmadaki nihilistik projelerinin en güçlü olanaklarından biri olduğunu ifade etmektedir. Lee'nin burada kastettiği, kişiye özgü alanlar sunan internetle, anlam yaratılabildiğidir. Daha açık bir deyişle, herkesin olayları kendi bakış açısı ile tekrar tekrar yorumlayabilme özelliğine sahip olan internetin nihilistik olduğudur. Çünkü internet üzerinden yapılan paylaşımlar ile kriz yaratmak, olayları abartmak, post-truth söylemlerin yayılmasına neden olmak kolay ve zahmetsizdir. İnternetin bu özelliği ile yine kolay ve zahmetsiz bir şekilde gerçeğin içi boşaltıldığından ve hakikat önemsizleştiğinden nihilizm ortaya çıkmaktadır (Lee, s. 9).

Medya ve nihilizm ile ilgili çalışmalara değindikten sonra medyanın yapısından ve bu yapının nihilizm ile olan bağlantısından bahsetmek gerekmektedir. Medya metinlerinin kültür endüstrisinin bir ürünü olduğu ve kültür endüstrisinin medya çalışmalarındaki 
anahtar kavramlardan olduğu göz önüne alındığında kültür endüstrisine değinmenin gerekliliği ortaya çıkmaktadır. Kellner'a göre, kültür endüstrisi, medya gösterilerini yeni alanlara yayarak çoğalmış ve gösteri; ekonomi, yönetim, toplum ve günlük hayatı düzenleyen kurallardan biri haline gelmiştir. Medya kültürü, seyirci çekmek ve medyanın gücü ile kârını arttırmak için, teknolojik açıdan gelişmiş gösteriler üretmektedir. Eğlence şekilleri, haberlerin içine işlemekte ve sansasyonel eğitim-eğlence kültürü giderek popülerleşmektedir. Bununla birlikte medya gösterisinin, politik ve toplumsal hayatı şekillendirmedeki rolü de giderek büyümektedir. Medya kültürü, sadece sürekli genişleyen zaman ve enerji dilimlerini işgal etmekle kalamamakta; fantezi, hayal, örnek düşünce ve davranış ile kimlikler için her zamankinden daha fazla malzeme sunmaktadır (Kellner, 2013, s. 19-20).

Medyanın eğlence şekilleri, medya metinlerinin içeriğinin boşalması anlamına gelmekle birlikte, medyanın ilgi çekmek için sansasyonel içeriklere yer vermesi, başka bir deyişle, olayı bağlamından koparıp, çarpıtması ya da abartması, yanılsamaya yol açtığından dolayı medyadaki nihilizme işaret etmektedir. Söz konusu medyadaki nihilizm de giderek daha çok popülerleşen medya metinleriyle yayılmaktadır.

Artık daha fazla malzeme sunar hale gelen medya kültürü ise medya tarafından ortaya konmakta ve "gerçek kültürü" ham madde olarak değerlendirmektedir. Medya, gerçek kültürün çeşitli yönlerini yeniden yaratarak, değiștirerek ve şekillendirerek kullanmaktadır. Medya modern insanın kültürel tercihlerini düzenlemektedir. Medya tüketicilerinin medyanın kendilerine sağladığ bağlı olarak özel bir medya mantığı gelişmiştir. Medya mantığı, iletişimin medyadaki düzenleniş biçimidir ve bu noktada medyanın kullandığı formatlar önem kazanmaktadır. Medya formatları içeriğin nasıl düzenleneceğini, üsluba nasıl uydurulup sunulacağını belirlemektedir (Lundby \& Ronning, 2014, s. 18-19).

Medyanın kültürü değiștirmesi ve hatta bazı yönlerini yok ederek yeniden yaratması da zaten nihilizmin kendisini oluşturmaktadır. Ancak şunu da dikkat çekmek gerekmektedir ki medyanın gerçek kültürü alıp, kendine göre, daha açık bir deyişle, daha fazla izlenme şekline göre düzenlenmesiyle ortaya çıkan medya kültürünün içeriği sorgulanmalı ve medyanın kâr odaklı yapısından dolayı, söz konusu medya kültürünün esasen çoğunlukla içeriği boş eğlenceden ibaret olduğu göz ardı edilmemelidir. Ayrıca medya mantığından bahsedilmektedir. Fakat medya ve medyadaki nihilizm genellikle mantıksızlığı beslemektedir.

Öte yandan modern toplumda medyanın giderek daha önemli bir yer edinmekte olduğu kabul görmektedir. Medya günümüzde toplumsal denetimin sağlanmasında olduğu gibi toplumsal değişmenin de başlıca araçlarından olan bir güç-iktidar kaynağı olarak görülmektedirler. Medya günlük yaşamda ün ve şöhrete giden en kestirme yolu oluşturarak toplumlarda "statü" sağlamanın temel araçlarından birisi haline gelmiştir. Aynı zamanda toplumsal yaşamda boş zamanı dolduran başlıca etkinlik olarak günümüzün en önemli "eğlendirme" aracıdır da. Bunlara ek olarak medya kamusal olayların yer aldığı bir alan oluşturmaktadır. Toplumsal yaşamda gerçekliğin ne olduğu konusunda tanımlar medya aracılığıyla oluşmakta ve aktarılmaktadır. Dolayısıyla medya topluma sürekli bir "anlam sistemi" sunmakta; olağan ve doğal olan ile olağandışı ve doğal olmayanın neler olduğunu göstermekte, kısacası normalin ne olduğunun başlıca belirleyicisi olmaktadır (Kaya, 1999, s. 23). 
Fakat bu noktada özünde boş zamanları doldurmak üzere eğlence aracı olarak tasarlanan medyanın, topluma anlam sistemi sunarak, başlıca şeylerin belirleyicisi haline gelmesi altı çizilmesi gereken bir konudur. Kurmaca ile kurmaca dışının birbirine karıştığı posttruth çağa, medyanın ilgi çekmek adına ürettiği sansasyonel içerikler eklendiğinde, medyadaki metinlerin ne kadar gerçek olduğu sorusu büyük bir önem arz etmektedir. Medya toplumdaki gerçekleri belirlese de esasen ticari yapısından dolayı gerçekleri yansıtma değil, ilgi çekip daha fazla para kazanma odaklı olduğundan olayları çarpıtma eğilimindedir. Keyes, medyadaki bu aldatmaca ile ilgili şunları söylemektedir: Aldatma, hayatını başkalarını eğlendirerek para kazananlar olduğu sürece eğlence dünyasında geçerliliğini korumuştur. Yeni olan gösteri dünyasının artık her yerde olması ve insanların onun değer sistemine olan duyarlılığıdır. Günümüz eğlence endüstrisindeki ahlak, geçmiştekinden daha düşük değildir. Ancak o dönemin insanları muhtemelen kendilerini gösteri dünyasındaki şahsiyetlere bu denli kaptırmamışlardır. Eskideki insanlar, gerçek hayattaki insanlara televizyondakinden daha çok bağlıydı (Keyes, 2017, s. 228).

Toplumsal denetimin ve anlam yaratmanın başlıca araçlarından olduğu ifade edilen medya, aynı zamanda tüm propaganda ve ideolojileriyle, günümüz toplumunda bireyleri yoğun saldırıya maruz bırakmakta ve günlük hayatı nerdeyse tamamen belirlemektedir. Ne yenileceğinin, ne giyileceğinin, ne yapılacağının ve en önemlisi ne düşünüleceğinin medyanın yönlendirmesiyle şekillendiği söylenebilir. Medya duygu ve düşünceleri ele geçirmekte, aynı zamanda da ürettikleri tek tip kalıplarla insanları ruhsuzlaştırmaktadır (Gülsoy, 2005, s. 185). Empoze ettiği sürü vizyonu ile sürü insanları oluşturan medya, aynı zamanda insanları ruhsuzlaştırararak duyarsızlaşlaştırmakta ve bir boşluğa sürüklemektedir. Söz konusu nihilist duygular, hem sosyal düzenin çökmesine hem de bireysel anlamın bozulmasına neden olarak var olan nihilizmi pekiștirmektedir.

Son olarak da simülakr, simülasyon ve hipergerçeklik kavramlarını ortaya atan Baudrillard'a parantez açmak medya ve nihilizm konusuna sağlayacağı yarar bakımından önemlidir. Baudrillard, simülakrları gerçeğin yerine koymakta ve artık hipergerçek bir dünyada yaşandığını ifade etmektedir. Bununla birlikte kitle iletişim araçlarını da hipergerçekliğin kendisi olarak görmektedir. Bu noktadan hareketle, ortaya attığı söz konusu kavramlarla medya çalışmalarına farklı bir perspektif getiren Baudrillard'da değinmek gerekmektedir.

Simülakr, bir gerçeklik olarak algılanmak isteyen görünüm iken, simüle etmek, gerçek olmayan bir şeyi gerçekmiş gibi sunmak, göstermeye çalışmaktır. Simülasyon ise bir araç, bir makine, bir sistem, bir olguya özgü işleyiş biçiminin incelenme, gösterilme ya da açıklanma amacıyla bir maket ya da bir bilgisayar programı aracılığıyla yapay bir şekilde yeniden üretilmesidir (Baudrillard, 2011, s. 6). Teknolojiyi araç olarak görmeyen Baudrillard, televizyonu hipergerçekliğin kendisi olarak ele almaktadır. Örneğin televizyon yaşamı temsil eden, yaşama ilişkin haberler ileten bir araç değil yaşamın kendisidir. Televizyon ekranından yansıyanların bir yerlerde bir karşılığı yoktur. Orada kendine özgü bir dünya vardır (Güngör, 2018, s. 209).

Baudrillard'a göre, medya artık simülasyon evrenine geçmiştir ve gerçek üstü bir dünya sunmaktadır. Burada geçmiş ve gelecek yoktur. İletişimde kodlayıcı ve kodaçıcı yoktur. İletilerin simülasyon ortamı vardır (Baudrillard, 2011, s. 58). Medya gerçeklikten de gerçek bir hipergerçeklik sunmaktadır. Simülakr gerçeği yutmuş ve gerçeğin önüne geçmiştir (Güngör, 2018, s. 269). Bu noktada artık hakikat ile kurmaca, gerçek ile simüle edilen, yüzey ile derinlik arasında bir bağlantı kurulamamaktadır (Stevenson, 2008, s. 
269). Haberler ve kitle ilişkisine de değinen Baudrillard, haberlerin, ister politik, ister eğitici, isterse kültürel içerikli olsun sonuç olarak niyetin, anlam ileterek kitleleri anlamın egemenliği alanda tuttuğunu söylemektedir (Baurdillard, 1991, s. 12; 22).

Sonuç olarak kendisini ve sistemi nihilist olarak nitelendiren postmodern düşünür Baudrillard'ın söylemleri medyayı anlamlandırma noktasında çok önemlidir. Baudrillard, artık eski nihilizm türlerinden farklı saydam bir nihilizm olduğunu savunmakta ve bu saydam nihilizmin, bir simülasyon ve derinlikten yoksun olduğunu ifade etmektedir. Baudrillard'ın söz konusu saydam nihilizmi, postnihilizm olarak da adlandırılmaktadır. Ayrıca Baudrillard'a göre, gerçeğin, modelin kopyasından başka bir șey olmaması ve simülasyon evrenine özgü saydamlığın bulanık olması, dışsal bir görünümden yoksun olmasından dolayı nihilizmin aşılıp geçilmesi de olanaksızdır (Baudrillard, 2011, s. 169; 172-173).

$\mathrm{Bu}$ noktadan hareketle, televizyonun simülasyon ile hipergerçeklik ürettiğini ifade eden Baudrillard, kendi deyimiyle televizyonun saydam nihilist yapısına dikkat çekmektedir. Çünkü O’na göre ortada gerçek değil, kopyalar ve gerçekten daha öte hipergerçeklikler söz konusudur. Ayrıca medyayla, simüle edilen ve gerçek, yüzey ile derinlik ve hakikat ile kurmaca arasındaki ilişkinin de yok olduğunu ifade eden Baudrillard, burada yine medyanın saydam nihilist karakterini vurgulamaktadır. Artık postmodern dünyada, modern dünyadaki hakikati arama fikri de terkedilmiştir. Çünkü hakikat diye bir şey yoktur ve herkes istediğine inanmaktadır. Hakikati dahi reddetme fikri, post-truth çağ ile nihilizm ilişkisini tekrar ortaya koymaktadır. Sistemin herkesi duyarsızlaștırdığını, aldırmaz bir tavır içerisine soktuğunu ifade eden Baudrillard, sistemin, insanların değerlerini ve amaçlarını yok ederek, nihilist duygular empoze eden yapısına da dikkat çekmektedir.

\section{Yöntem}

Medya ve nihilizm ilişkisinin irdelendiği çalışmanın problemi, bu ilişkinin nasıl olduğu sorusuna cevap bulmak; amacı ise medyada nihilizmin olup olmadığını ortaya koymaktır. Bu bağlamda söylem analizi yönteminin kullanıldığı çalışmada, örnekler, araştırmanın amacına uygun örneklerin seçilmesi yöntemi olan amaçsal örnekleme metodu ile seçilmiştir. Tüm medyadan örnek verebilmek adına gazete haberi, televizyon haberi, sosyal medya paylaşımı, televizyon gündüz kuşağı programı, televizyon prime time yayını ve sinema filminden örneklem alınmıştır. Ancak sayfa sayısı sınırlılığından dolayı örneklemler birer tane ile sınırlandırılmıştır. Bu bağlamda bir gazete haberi, bir ana haber bülteni haberi, bir adet sosyal medya paylaşımı, gündüz kuşağı programlarından "Müge Anlı ile Tatlı Sert" programı, prime timedan "Arka Sokaklar" dizisi ve "Borç Harç" sinema filmi incelenmiştir. Söz konusu incelemeler "Medya ve Nihilizm: Türk Medyası Örneği" isimli doktora tez çalışmasında üretilen aşağıdaki tablo referans alınarak yapılmıştır. Tabloda, nihilizm türlerine ayrıştırılmış ve her nihilizm türü için parametreler belirlenmiștir. İncelenen metinlerde, söz konusu parametrelerden bir veya daha fazlası görüldüğünde, parametrenin ait olduğu nihilizm türünün olduğu öne sürülmüştür. 
Tablo 1: Nihilizm Türleri ve Parametreleri

\begin{tabular}{|c|c|c|c|c|c|c|}
\hline Nihilizm & $\begin{array}{l}\text { Epistemolojik } \\
\text { Nihilizm }\end{array}$ & $\begin{array}{l}\text { Varoluşsal } \\
\text { Nihilizm }\end{array}$ & $\begin{array}{l}\text { Saydam Nihilizm/ } \\
\text { Postmodern Nihilizm }\end{array}$ & $\begin{array}{l}\text { Aktif } \\
\text { Nihilizm }\end{array}$ & Pasif Nihilizm & Politik Nihilizm \\
\hline $\begin{array}{l}\text { Medyanın } \\
\text { dönüşen rolleri }\end{array}$ & $\begin{array}{l}\text { Kriz ve } \\
\text { başarısızlık } \\
\text { söylemi }\end{array}$ & $\begin{array}{l}\text { Karanlık ve } \\
\text { mutlu sonun } \\
\text { olmadığı } \\
\text { hikâyeler }\end{array}$ & -mış gibi yapma & $\begin{array}{l}\text { Umudunu } \\
\text { kaybetme }\end{array}$ & $\begin{array}{l}\text { Yönünü } \\
\text { kaybetme }\end{array}$ & $\begin{array}{l}\text { Siyasi } \\
\text { bir amaç } \\
\text { doğrultusunda } \\
\text { hareket etme }\end{array}$ \\
\hline $\begin{array}{l}\text { Mantıksızlığın } \\
\text { beslenmesi }\end{array}$ & Bir olayı abartma & $\begin{array}{l}\text { Pesimizm, } \\
\text { umutsuz, } \\
\text { bunalım ve } \\
\text { çöküntü } \\
\text { içinde olma }\end{array}$ & $\begin{array}{l}\text { Saydamlık ve } \\
\text { boşlukta yüzer } \\
\text { gibi olma hali }\end{array}$ & $\begin{array}{l}\text { Bir } \\
\text { dünyaya } \\
\text { ait olmayan } \\
\text { değerler }\end{array}$ & $\begin{array}{l}\text { Değerlerin } \\
\text { olmadığı } \\
\text { bir dünya }\end{array}$ & $\begin{array}{l}\text { Mevcut } \\
\text { sistemi } \\
\text { koruma } \\
\text { çabası }\end{array}$ \\
\hline $\begin{array}{l}\text { İdeolojisizlik, } \\
\text { amaçsızlık, } \\
\text { değersizlik ve } \\
\text { yeni değerler } \\
\text { biçme, yeniden } \\
\text { üretme }\end{array}$ & $\begin{array}{l}\text { Yalan haber } \\
\text { yapmak }\end{array}$ & $\begin{array}{l}\text { Umursamama } \\
\text { hali }\end{array}$ & $\begin{array}{l}\text { Simülasyon ve } \\
\text { hipergerçeklik }\end{array}$ & $\begin{array}{l}\text { Yıkma } \\
\text { isteği }\end{array}$ & $\begin{array}{l}\text { Saldırmayan, } \\
\text { bitkin ruh }\end{array}$ & $\begin{array}{l}\text { Mevcut } \\
\text { sisteme karşı } \\
\text { çıkma çabası }\end{array}$ \\
\hline $\begin{array}{l}\text { Değerlere bağı } \\
\text { olmama hali } \\
\text { sona ermiş } \\
\text { ve değerlerin } \\
\text { farkında olmama } \\
\text { başlamış }\end{array}$ & $\begin{array}{l}\text { Olayları } \\
\text { çarpıtmak, } \\
\text { bağlamından } \\
\text { koparmak ve } \\
\text { yeni bağlam } \\
\text { içerisinde yeniden } \\
\text { vermek/yeniden } \\
\text { kurgulamak }\end{array}$ & $\begin{array}{l}\text { Yabancılaşma, } \\
\text { kimlik krizi }\end{array}$ & $\begin{array}{l}\text { Derinlik yok, boşluk } \\
\text { ve anlamsızlık var }\end{array}$ & Şiddet & $\begin{array}{l}\text { Dünyanın } \\
\text { değerlerini } \\
\text { ve tutkuları } \\
\text { istenmez }\end{array}$ & \\
\hline Ahlaksal çöküntü & $\begin{array}{l}\text { Post-truth } \\
\text { söylemler }\end{array}$ & $\begin{array}{l}\text { Duyarsızlık, } \\
\text { duygusuzluk, } \\
\text { ruhsuzluk. }\end{array}$ & $\begin{array}{l}\text { Gerçek yoktur } \\
\text { denilememekte, } \\
\text { fakat aynı zamanda } \\
\text { mutlak doğruluk fikri } \\
\text { de reddedilmekte }\end{array}$ & $\begin{array}{l}\text { Terör; } \\
\text { radikal } \\
\text { nihilist } \\
\text { tutkudur }\end{array}$ & & \\
\hline $\begin{array}{l}\text { Eğlence odaklı } \\
\text { olması, eğlence } \\
\text { endüstrisi ve } \\
\text { kültür endüstrisi }\end{array}$ & Sansasyonellik & $\begin{array}{l}\text { Keder, korku } \\
\text { ve hayal } \\
\text { kırıklı̆ı̆ }\end{array}$ & $\begin{array}{l}\text { Orijinali olmayan bir } \\
\text { kopya ve derinlik } \\
\text { içermeyen bir yüzey }\end{array}$ & & & \\
\hline $\begin{array}{l}\text { Dışsal anlamda } \\
\text { sosyal düzenin } \\
\text { çökmesi, içsel } \\
\text { anlamda bireysel } \\
\text { anlamanın } \\
\text { bozulması }\end{array}$ & $\begin{array}{l}\text { Hakikat } \\
\text { önemsizleşmekte } \\
\text { ve gerçeğin içi } \\
\text { boşaltılmakta }\end{array}$ & Narsisim & $\begin{array}{l}\text { Tanıdıklık/aşinalık, } \\
\text { yakınlık duygusu }\end{array}$ & & & \\
\hline $\begin{array}{l}\text { Tek tip insan } \\
\text { yaratma çabası; } \\
\text { sürü insanı, } \\
\text { sürü vizyonu }\end{array}$ & $\begin{array}{l}\text { Olayları göz } \\
\text { ardı etmek }\end{array}$ & $\begin{array}{l}\text { Daha alaycı } \\
\text { bir tavır }\end{array}$ & & & & \\
\hline Hayranlık & $\begin{array}{l}\text { Olayları } \\
\text { birleştirmek }\end{array}$ & & & & & \\
\hline $\begin{array}{l}\text { Teknik eylemin } \\
\text { içine sıkışmak; } \\
\text { Teknik özünde } \\
\text { nihilisttir }\end{array}$ & $\begin{array}{l}\text { Yanılsama evreni } \\
\text { yaratmak }\end{array}$ & & & & & \\
\hline $\begin{array}{l}\text { Zamansızlık } \\
\text { ve uzamsızlık } \\
\text { (herhangi bir } \\
\text { değerden yoksun } \\
\text { mekân, nihilistik } \\
\text { mekândır) }\end{array}$ & & & & & & \\
\hline $\begin{array}{l}\text { Eşitlikçi bir } \\
\text { duygusuzluk } \\
\text { olan bayağılık }\end{array}$ & & & & & & \\
\hline $\begin{array}{l}\text { Komedi; hiçbir } \\
\text { amacı olmayan }\end{array}$ & & & & & & \\
\hline $\begin{array}{l}\text { Romantizm; } \\
\text { hiçbir amacı } \\
\text { olmayan }\end{array}$ & & & & & & \\
\hline
\end{tabular}




\section{Nihilizmin Türk Medyası Üzerinden Okunması}

\section{Örnek 1:}

|Gündem

\section{Melih Gökçek'ten skandala ilişkin çağrı! 'İmamoğlu bu ş̧erefsizliği yapanı derhal bul'}

Melih Gökçek sosyal medya hesabından, gündeme gelen ISKi'nin kanalizasyon kapağındaki Allah yazıısıa iliş̧in ą̧ılamalarda bulundu. Skandala ilișkin paylaşım yapan Gökçek, Ekrem Imamooğluna çağrıda bulundu. iski'nin kanalizasyon kapağındaki durumu gören bir vatandaş yazıyı silmek için eline jeneratör alarak her yeri dolaştı.

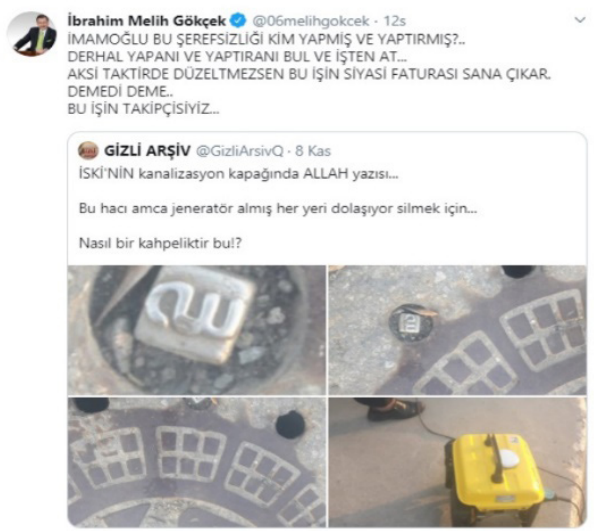

Görsel 1: ISKİ Kanalizasyon Haberi

Yeni Akit gazetesinin internet sitesinde yer alan haberde İSKİ'nin taktırdığı kanalizasyon kapaklarında Arapça Allah yazdığı iddia edilmektedir. Fakat esasında 2006 yılında takıldığı ortaya çıkan kapaklardaki yazıda, kapakları üreten firma olan Mert Döküm'ün baş harfleri yer almaktadır. Yeni Akit gazetesinin, Melih Gökçek'in söylemlerine yer vererek, "skandala ilişkin" ifadesini kullanması ve aynı şekilde kapaklarda Allah yazdığını iddia etmesi sansasyonellik, haberde çarpitma, post-truth ${ }^{1}$ söylemler yayma ve gerçeğin içinin boşaltma gibi epistemolojik nihilist önermeler taşımaktadır. Çünkü, haberin doğruluğunu, başka bir deyişle, Allah yazdığını ispatlamadan, olayı haberleștirmek, hakikatin göz ardı edilerek ve gerçeğin önemsenmeyerek, gazetenin ideolojisi doğrultusunda söylemler yaydığını ortaya koymaktadır ki bu da post-truth söylemlere işaret etmektedir. Ayrıca, yine gerçek olanın geri plana atılmasından dolayı, gerçeğin içinin boşaltılması söz konusudur. Çünkü daha önce de değinildiği üzere, kapaklarda Arapça Allah değil, Mert Döküm'ün baş harfleri yer almaktadır. Tüm bu sebeplerden dolayı, haberin içeriği bilinçli olarak saptırıldığı için çarpıtma ve "skandal" gibi kelimelerin kullanılmasından dolayı da sansasyonellik vardır. Öte yandan haber, siyasi bir amaç doğrultusunda hareket etme ve mevcut sisteme karşı çıkma çabası olduğundan politik nihilizme, zamansızlık ve uzamsızlık parametresiyle de nihilizme işaret etmektedir.

\section{Örnek 2:}

Bu örnekte Fox Tv ve A Haber'in Libya tezkeresi ile ilgili haberleri incelenmiştir. Fox $T v$ 'de yer alan haberde, Libya tezkeresi eleştirilmekte ve tezkerenin ucunun açık olduğu, yetkilerin sadece Cumhurbaşkanı'nda olduğu, niçin gidildiğinin bilinmediği, kaç askerin gönderileceğinin de belli olmadığını söylenerek, eleştiri sunulmaktadır. Ayrıca, muhaliflerin yorumlarına da haberde yer verilmektedir. Kararın siyasi olduğu ve bu yüzden siyasi sonuçlarının olacağı, bunu da ülke olarak hep birlikte yaşayacağımız belirtilmektedir. A Haber'de ise tam tersi bir haber dili söz konusudur. Haberde, tezkerenin sağlayacağını söyledikleri getirileri maddeleştirerek anlatmaktadırlar. Sunucu, ne kadar askerin, nereye, ne zaman gideceği ile ilgili konuların, ilgili kurumlar tarafından zaten organize edileceğini ifade etmektedir. Söz konusu haberler, aynı haberin, farklı ideolojilerdeki kanallarda verildiğinde de aynı sonucu, daha açı bir deyişle yine ikisinin de epistemolojik nihilist haber olabileceğine dair iyi bir örnek teşkil etmektedir. Fox Tv, tezkereye yönelik eleştirilerinin yanı sıra, bunun bedelini tüm ülkenin ödeyeceği yönünde kurduğu haber diliyle kriz ve başarısızlık söylemi yaratırken; A Haber ise olayı abartarak 
görkemli hale getirmektedir. Her iki parametre de haberleri epistemolojik nihilizm kategorisine sokmaktadır. Ayrıca siyasi bir amaç doğrultusunda hareket etme, mevcut sistemi koruma çabası ile mevcut sisteme karşı çıkma çabası olduğundan her iki haber aynı zamanda politik nihilizm kategorisine girmektedir. Bununla birlikte sundukları ideolojik metinlerle, sürü vizyonu aşıladıkları ve tüm bunlar doğrultusunda da medyanın dönüşen rolüne işaret ettikleri için nihilizmden de söz edilebilmektedir.

\section{Örnek 3:}

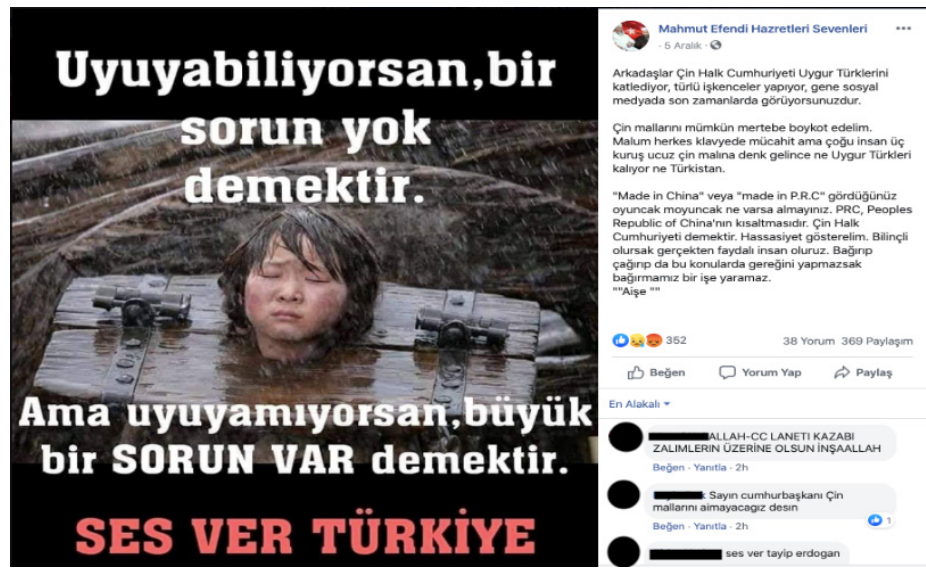

Görsel 2: Uygur Türkleri Paylaşımı

Yeni iletişim teknolojilerine ait mecralarda sıklıkla karşılaşılan Uygur Türkleri'ne yapılan zulümle ilgili birçok yanlış paylaşım söz konusudur. Söz konusu örnekteki paylaşım da bunlardan biridir. "Mongol: The Rise Genghis Khan" filmine ait bir görüntü, yine Çin'in Uygur Türkleri'ne yaptığı işkence görüntüsü olarak verilmektedir. Bu yüzden söz konusu paylaşımda, olayı bağlamından koparıp, yeni bağlam içerisinde verme ve posttruth söylem yayma unsurlarıyla epistemolojik nihilizm mevcuttur. Çünkü, bir film karesinin alınıp, gerçekmiş gibi verilmesi, olayın bağlamından koparılıp, yeni bağlam içerisinde verilmesine ve gerçeğin göz ardı edilerek, gerçek dışı söylemlerin ortaya konmasıyla, post-truth söylemlere işaret etmektedir. Buna ek olarak, örnekte bir kriz ortamı yaratma çabası da vardır. Çünkü, Türklere yapıldığı iddia edilen zulümle ve gerçek olmayan bu paylaşımlarla, ayrıca insanlardan vermesi istenilen tepkiyle kriz yaratılmaya çalışılmaktadır. Tüm bunlar da yanılsama evrenine yol açmaktadır. Bu noktadan hareketle, kriz söylemi ve yanılsama evreni de epistemolojik nihilizmin parametrelerinden olduğundan, bu örnekteki epistemolojik nihilizm bulgusu güçlenmektedir. Bununla birlikte, siyasi bir amaç doğrultusunda hareket etme ve mevcut sistemi koruma çabası da olduğundan politik nihilizm ile zamansızlık ve uzamsızlık parametresiyle nihilizm vardır.

\section{Örnek 4:}

ATV'de yayınlanan "Müge Anlı ile Tatlı Sert" programı, dolandırıcı, katil vs. gibi suçluların ya da kayıp kişilerin bulunması veya cinayetlerin aydınlatılması gibi polisiye olayların ele alındığı ve çözülmeye çalışıldığı bir reality showdur. Özellikle evlilik programlarının kaldırılmasından sonra bu formatta çok fazla program yapılmasına rağmen "Müge Anlı ile Tatlı Sert" içlerinde en çok izlenendir. Bir psikiyatrist, bir adli tıp uzmanı ve bir avukatın da bulunduğu programda, moderatör ise araştırmacı gazeteci Müge Anlı'dır. Ele aldığı konular itibari ile programın genel anlamda izleyicileri, umutsuz, bunalım ve çöküntü içinde olmaya sürüklediği, ayrıca her gün sunduğu polisiye olaylarla izleyicileri duyarsızlaştırıp, duygusuzlaştırdığı ve buna ek olarak da korku hissi uyandırdığı için, izleyicileri varoluşsal nihilizme götürdügü söylenebilir. Ayrıca cinayetlerin şov şeklinde 
verilmesinden, başka bir deyişle, kültür endüstrisinin her şeyin içini boşaltan yapısından dolayı, şova dönüştürülen suçlar ile değerler alt üst edildiğinden nihilizmden de bahsetmek mümkündür.

Tüm bunların yanı sıra değinilmesi gereken başka bir nokta da zaman zaman yaptıkları yanlış yönlendirmelerdir. Buna bir örnek olarak Eylül 2018'de Sedanur Güzel isimli 9 yaşındaki bir kızın köyünde kaybolmasıyla ilgili yaptıkları arama çalışmaları ele alınabilir. Sedanur kaybolduktan sonra ailesi Müge Anlı'ya başvurmuştur. Bir süre devam eden yayınlar sırasında aile ve zaman zaman da köyden bazı kişiler programa gelmekte, ayrıca olayın gerçekleştiği Kars'ın Kağızman köyünde de bir ekip durmakta ve olayı yakından takip ederek, sık sık köyden kişilerle birlikte canlı yayına bağlanmaktadırlar. Canlı yayın sırasında köyden üç kişi Himmet Uç isimli kişiyi olay günü elinde eldivenlerle gördüklerini söyledikten sonra dikkatler Himmet Uç’un üzerine yoğunlaşmaktadır. Özellikle adli tıp uzmanı ve Müge Anlı, zaman zaman da psikiyatrist ile avukat Himmet Uç'a sorularak sorarak, sıkıştırmaktadırlar. Himmet kendisine iftira atıldığını söylediğinde ise adli tıp uzmanı, "Sana iftira atmaları için gerekçeleri var mı" diye sormaktadır. Bunun üzerine Himmet "Beni mazlum olarak bu olaya seçmeyin, beni bu olaya kurban vermeyin... Saatleri karıştırdığım için bu olayda benim çok üzerime geliniyor" demektedir. Himmet'in tepkisinden yola çıkarak Müge Anlı, adli tıp uzmanı, avukat ve psikiyatrist Himmet'in üzerine daha çok gitmektedir. Sonrasında ise Himmet'e çok çelişkili konuştuğunu ve o günle ilgili şeylerin unutulmayacağını söylemektedirler. Buna karşılık ise Himmet kendisine iftira atıldığını ve bu olayla ilgisi olmadığını sıklıkla tekrarlamaktadır. Yayına bağlanan "ismini vermek istemeyen izleyici", olay günü Himmet Uç’u alkol alırken gördüğünü ifade etmektedir. Himmet ise "Hayır, ben içmiyorum. Ne alkolü? Vicdanı körelmiş bunların" demektedir. Üzerine daha fazla gidilince ise Himmet küçük bir sinir krizi geçirerek “Şerrinizi benim üzerime atmayın. Benim vicdanım temiz... Allah’ınız Peygamber'inizi seviyorsanız benden uzak durun" demektedir.

Başka bir programda ise Müge Anlı "Himmet denilen kişi ile burada tanıştık biliyorsunuz. Aslında ben başta dedim ki herhalde hali böyle bu adamın... Fakat bir süre sonra o kadar çelişki ortaya koydu ki... Dün de yayını karıştırdı. Akşam da polis geldi Himmet'i aldı götürdü" demekte ve Himmet'in polisler tarafından götürülüşü gösterilmektedir. Bu sırada stüdyodaki seyirciler de alkışlamaktadır. Hazırladıkları kısa videoda da Himmet'in çelişkili ifadeleri art arda sıralanmaktadır. Müge Anlı Himmet Bey'in karakteri böyle heyecanlıymış gibi geliyor demekte, ancak hemen sonrasında da polisleri görünce şoke olduğunu eklemektedir. Daha sonra da "Önce köydeki hareketleri dikkat çekmedi sanırım. Ama daha sonra yayında yaptığı açıklamalar ve kamuoyunun gösterdiği haklı tepki sayesinde yetkililerin dikkatini çekti... Tamamen yaptığı çelişkili açıklamalar... Kamuoyu baskısı yüksek, insanlar haklı" demektedir.

14 Ocak 2020 tarihinde yapılan yayında ise mahkeme sonuçlanmış ve Sedanur'un annesi ile amcası yayına gelmiştir. Üç kişinin yargılandığı davada Erkan Bozkurt ve Ahmet Bilen ağırlaştırılmış müebbet cezası alırken, Himmet Uç ise beraat etmiştir. Fakat Himmet'in yaklașık 8-9 aydır hapiste olduğu da ifade edilmektedir. Müge Anlı “... Bir de Himmet'imiz vardı. DNA testi olmasaydı çıkma ihtimali yoktu. Ben en başından beni Himmet'in bu tecavüz suçuna karışabileceğine inanmadım. Gözü aydın...” demektedir. Dış ses Müge Anlı'nın, Erkan Bozkurt'un çelişkili ifadelerine dikkat çektiğini söylemekte ve sonra da Sadanur'un cinayetiyle ilgili geçmiş programlarda yapılan yayınlardan kurgulanmış bir görüntü izletilmektedir. Bu görüntülerde sıklıkla Müge Anlı'nın, Himmet'in yapıp yapmadığı konusunda şüpheleri olduğu söylemlerine yer verilmektedir. Fakat programlar 
izlendiğinde ise bu tarz cümlelerin öncesinde ve sonrasında Himmet'in çelişkili ifadelerine daha fazla dikkat çekerek, halkın haklı olarak tepki gösterdiğini de eklediği görülmektedir. Sedanur'un annesi "Çocuklar korkuyor, Himmet hapisten çıkmış, yine köye mi gelecek diye soruyorlar" demekte, Müge Anlı ise "Himmet'in konu ile ilgisi yok ama" demesine karşın, Sedanur'un annesi de "Çocuklar korkuyor” diye cevap vermektedir.

Bu örnekte Himmet Uç isimli kişi heyecanlı bir karaktere sahip olduğu için ve özellikle adli tıp uzmanı tarafından çok fazla sıkıştırıldığı için paniklemiş ve olay günü ile ilgili çelişkili ifadeler vermiştir. Bunun üzerine Müge Anl, avukat ve psikiyatrist daha fazla üzerine gitmiş ve Himmet Uç hedef gösterilmiştir. İzleyiciler de suçlunun Himmet Uç olduğunu düşünmeye başlamış ve sosyal medya üzerinden tepki gösterdikleri için de Himmet Uç tutuklanmıştır.

Sorgu odasında suçluları çapraz sorguya çeken polislerin tavrıyla suçlu olduklarını düşündükleri kişileri sorgulayan "uzman" kișiler, söz konusu sorgunun televizyonda yapıldığını, haberlere yansıdığını ve sosyal medyada konuşulduğunu göz ardı etmektedirler. Suçlu olma ihtimalinden dolayı Himmet Uç'un üzerine gidip sıkıştırmaları, "ismini vermek istemeyen izleyici"lerin iddialarını doğru kabul etmeleri, üzerine gelindiği için gerilince, haklı olduklarını düşünerek daha da çok üzerine gitmeleri ve "neden sinirleniyorsun ki" diye, tecavüz ve cinayetle suçlanmayı sıradan bir şeymiş gibi göstermeleri programın formatıyla ilgili sıkıntıları ortaya koymaktadır. Amaç suçluları ortaya çıkarmak olsa da şov programı için haddini fazlasıyla aşan bir durum söz konusudur. Ayrıca Himmet'in tutuklandığı programı sunarken Müge Anlı'nın "Himmet denilen adam" derken, beraat ettiği gün "Himmet'imiz" söylemi, yine beraat ettiğinde "Ben zaten en başından beri inanmadım" derken, önceki programlarda sıklıkla çelişkili ifadeler vermesine dikkat çekmesi, videolarla yaratılan algl ve bunun sonucunda da kamuoyu baskısıyla Himmet'in 8-9 aydır hapiste olması, ayrıca artık köyünde de istenmemesi programdaki ikiyüzlülügü ve insanların hayatını ne kadar etkileyebildiğini ortaya koymaktadır. Ancak Himmet'in hapis cezası alması ya da böyle bir yaftalamaya maruz kalmasında kendilerinde herhangi bir suç olduğunu düşünmeyen programcılar, biz zaten inanmamıştık demekle yetinmektedirler. Bu bağlamda söz konusu örnek yalan, post-truth söylemler, olayı bağlamından koparma, yeni bağlam içerisinde yeniden verme, yanılsama evreni yaratma ve hakikatin önemsizleşmesi gibi epistemolojik nihilizmin birçok parametresini taşımaktadır. Programın sunucularının söylemlerindeki çelişkiler ve söylenen yalanlardan dolayı ahlaksal çöküntünün, ayrıca dışsal anlamda sosyal düzenim çöküşü, içsel anlamdan bireysel anlamın bozulmasının, programın formatı itibari ile medyanın dönüşen rolünün ve bununla bağlantılı olarak da nihilizmin söz konusu olduğu söylenebilir.

\section{Örnek 5:}

Kanal D'de yayınlanan Arka Sokaklar dizisi bir polisiye dizisidir. İstanbul'daki bir sivil polis ekibinin olaylara müdahale etmesi üzerinedir. Rıza karakteri başkomiser, Aylin, Ali, Murat, Hüsnü, Mesut, Murat ve Zeynep ise komiserdir. Dizi uçaktan inen yolcular ile başlamaktadır. Taksi şoförü kılığına girmiş komiser Murat, bir kadın yolcuyu almaktadır. Sonrasında başka bir yer gösterilmektedir. Burada da gözcülük yapan iki komiser Aylin ve Mesut vardır. Murat kadını, Aylin ve Mesut'un da olduğu yere getirmektedir. Taksideki kız, gözlenen adamlardan birini arayıp, taksiye çağırmakta ve uyuşturucu dolu bir çanta vermektedir. Mekânın önünden ayrıldıktan sonra taksideki kızı polisler almaktadır. Mekândaki adamlara da baskın düzenlenmektedir. Ancak adamlardan biri Aylin'i rehin almaktadır. Olayın sonunda adamlar yakalanmakta, Aylin kurtarılmaktadır. 
Olayın sonrasında komiser Zeynep görülmektedir. Annesi ile konuşmasından Zeynep'in babasının şehit bir polis olduğu öğrenilmektedir. Zeynep de asayișteki sivil ekibe katılmaktadır. Onun ilk iş günü ekipten komiser Osman'ın son günüdür. Osman emekliye ayrılmakta ve ona veda için kutlama yapılmaktadır. Ayrıca Komiser Mesut'un eski bir özel harekât polisi olduğu, arkadaşları önünde öldüğü için öfke kontrolü sorunu olduğu ve alkol bağımlısı olduğu öğrenilmektedir.

Ekipten Murat'ın, Zeynep ilgisini çekmiştir. Karakterlerle ilgili kısa kısa bilgilerin verildiği ilk bölümde Murat'ın Yavuz adında doktor bir kardeşi ve annesi olduğu, Zeynep'in annesi ile yaşadığı ve babasının şehit olduğu, Rıza'nın Ayla isimli eși ve Pınar isimli kızı olduğu, Hüsnü'nün Suat isimli eşi olduğu ve eşinin hamile olduğu, aynı zamanda dört çocuklarının daha olduğu ve dedesinin de onlarla kaldığı anlatılmaktadır. Hüsnü maddi sıkıntılar çekmekte, küçük bir evde, kalabalık bir şekilde yaşamaktadır. Mesut eşi Yeşim’den boşanmıştır. Bir çocukları vardır ve Yeşim ikinci evliliğini yapmıștır.

Karakter tanıtımlarından sonra iş hayatına dönülmektedir. Ekip devriyeye çıkmakta ve Rıza Başkomiser, aralarına yeni katılan Zeynep’e “Biz bir acil müdahale ekibiyiz. Genelde merkezden yönlendiriliriz. Bazen de sokaktaki adamlarımızdan haber gelir... Sokaklar önemlidir. Sokakların dilini çözmek şart, onu çözdün mü bu şehir senin” demekte ve esasen seyirciye işleri ile ilgili bilgi vermektedir.

Devriye gezerlerken bir kapkaç haberi gelmektedir. Kapkaça uğrayan bir şehit annesidir ve oğlunun yadigârı olan eşyalar çalınmıștır. Rıza, çantayı bulacağını söylemekte ve bularak teslim etmektedir. Emekliye ayrılan Osman ailesi ile alışverişe çıkmaktadır. Eşine sürpriz yapmak için ailesinin yanından ayrılan Osman, şahit olduğu bir hırsızlık olayına müdahale ederken, bıçaklanarak şehit olmaktadır.

Osman’ın cenaze töreni yapılmaktadır. Bu sırada Mesut alkol bağımlılığı ile ilgili tedavi görmek için rehabilitasyon merkezinde başka bir isimle yatmaktadır. Mesut, Osman Komiser'in haberini televizyonda görmekte, televizyonu tekmeleyerek, hastaneden kaçmaktadır. Ekip, Mesut'u bir sokakta içki içerken bulmaktadır, sonra da alıp götürmektedir.

Dizide her bölümde farklı farklı ve birden fazla olay çözülmektedir. Fuhuş için kadınlar gözaltına alınırken, aynı anda suçlu birinin yeri tespit edilip, baskına gidilmektedir. Osman'ı bıçaklayarak, şehit eden kişiyi, baskınla yakalamaktadırlar. Osman'ın eşi polis merkezine gelip, "Osman'ı niye öldürdün?” diye yakarıșta bulunarak, ağlamaktadır. Diğer taraftan ise Mesut'un rehabilitasyon süreci gösterilmektedir.

Osman'ı öldüren çocuk üzerinden bir çeteye ulaşılmaktadır. Ekibin bir sonraki hedefi çeteyi çökeltmek olmaktadır. Ekibin başı Ethem çocukları kaçırarak çeşitli suçlara yönlendirmekte, yeterince iş yapmayan çocuklara ise işkence etmektedir. Ekip çeteye ulaşmaktadır. Ancak Ethem kaçmaktadır. Fakat olayın sonunda Ethem de yakalanmaktadır. Ana olaylara ek olarak karakterler arasında da birçok olay yaşanmaktadır. Örneğin Rıza'nı kızı Pınar barda şarkı söylemektedir ve ekipten Murat'a âşıktır. Hüsnü'nün evinde sorunlar yaşanmaktadır. Zeynep ile Murat arasında ise ilişki başlamak üzeredir. Mesut'un terapilerde anlattıkları ile başından geçenleri ve niye alkol bağımlısı olduğu seyirciye anlatılmaktadır. Bunun gibi olaylar, çözülmeye çalışılan polisiye olaylar kadar yer kaplamaktadır. 
Dizi genel olarak ele alındığında popüler sinema filmleri gibi herhangi bir amaçtan yoksundur. Aksiyon, aşk ve drama gibi birçok şeye yer veren dizide sürekli tekrar eden farklı farklı polisiye olayları ile seyircinin eğlenmesi hedeflenmektedir. Daha açık bir deyişle, cinayet, hırsızlık gibi polisiye olayların tekrar tekrar işlendiği dizide, bu olayları pekiştirmek adına aşk ve drama da bolca ișlenmektedir. Her bölümde birden fazla olayın konu edinilmesinden dolayı da mantık hataları ve boşluklar olmaktadır. Bu noktadan hareketle dizinin hiçbir amacının olmadığını söylemek mümkündür. Dizi mantıksızlığın beslenmesi, ideolojisizlik, amaçsızlık, değersizlik, eğlence odaklı olması, bayağılık ve komedi parametreleriyle nihilisttir. Ayrıca izleyicide dizi karakterlerine karşı bir hayranlık duygusu oluştuğundan, diğer parametrelere ek olarak nihilizmin hayranlık parametresine de sahiptir. Söz konusu dizi gibi amaçsız dizileri, düzenli olarak izleyen izleyici çevresinde olup bitenlere karşı umursamaz, duyarsız ve duygusuz olabileceğinden, bu tarz dizilerin izleyicileri varoluşsal nihilizme sürüklediği söylenebilir. Bununla birlikte simülasyon evreninde -mış gibi yapan oyuncularla, orijinali olmayan bir kopya olan diziler üretildiğinden, ayrıca derinliğin olmamasından, boşluk ve anlamsızlığın olmasından, her hafta izlenerek, tüm hayatlarına şahit olunan dizi oyuncuları ile tanıdıklık, yakınlık duygusu kurulduğundan ve dizideki dünya ile karakterlerin, gerçek hayattan ve hatta gerçek hayattaki kişilerden daha gerçek algılanması, yani hipergerçeklik üretilmesinden dolayı da saydam/postmodern nihilizm vardır.

\section{Örnek 6:}

Efe Hızır’ın 2019 yılında çektiği Borç Harç filmi komedi türündedir. Film bir düğünle başlamaktadır. Düğünde takıları dron ile toplayan gelin ve damat, Ret Tv'de çalışan Murat, Ezgi ve Yunus tarafından haber yapılmaktadır. Gelinin babaannesi altınları alıp kaçmakta, arkasından biri ateş etmekte, Murat da anons çekmektedir. Ancak esasen bu sahnede haber muhabirleri ve anons çekiş tarzları ile dalga geçilmektedir.

Psikoloğa giden Murat'ın evlenmek üzere olduğu ve çok borcu olduğu öğrenilmektedir. Murat'ın psikolog ile olan diyaloğunda da psikologların eleştirildiği görülmektedir. Odada psikoloğun şişme bebeği vardır. Murat, şişme bebek ile psikoloğun fotoğrafını çekerek, internete koymakla tehdit etmektedir. Ayrıca bu seans ve geleceği diğer seanslar için de para ödemeyeceğini belirtmektedir.

Murat'ın sevgilisi Ceren'in, Murat'ın kendisini aldattığından şüphelenmektedir. Murat'ın aralarını düzeltmek için yaptıklarından, dergide okuduğu bir yazı üzerine Murat'ın kendisini aldattığına kanaat getiren Ceren, evdeki her şeyi kırıp dökerek evden ayrılmaktadır. Patronu Kudret, Murat'a bir anlaşma teklif etmektedir. "Benim sahte cenazemi kaldırırsan, kanalın yarısı senin olacak, borcun da kalamayacak" diyen Kudret'in teklifini, Murat kabul etmektedir. Kanalın yarısı da Kudret'in kızına kalacaktır.

Murat sahte cenaze işi için psikoloğu yine tehditle çağırmıştır. Burada psikoloğun kadınlarla hiç ilişki yaşamamış, bu yüzden "Aa kadın!" diye tepkiler veren biri olması dikkat çekicidir. Sahte cenazeyi düzenleyen Murat ve arkadaşları Ezgi ile Yunus cenazede pizza dağıtmaktadırlar. Pizza fikri Ezgi'ye aittir. Murat'ın gösterdiği tepkiye "Ne var işte herkes mutlu" yanıtını vermektedir. Elinde sürekli telefon olan Ezgi karakterinin bu söylemi ile Şeyma Şubaşı'nın kitabında yer alan "Herkesi mutlu edemezsin, çünkü pizza değilsin" sözüne gönderme yapılmaktadır.

İmam rolü yapacak olan psikolog, evde unutulunca imam Murat olmaktadır. Murat son anda tabutun boş olduğunu fark etmektedir. Yunus ve Ezgi cenaze töreninde 
gömebilecekleri bir şey ararken, Murat cemaati oyalamak için tekrar tekrar cenaze namazı kıldırmakta ve "Hakkını helal etmeyen yok mu? Neler söyleyeceksiniz?" gibi konuşup, sohbet etmektedir. Bu esnada Yunus ve Ezgi gömmek için cansız manken bulmuşlardır. Sonrasında cenaze gömülmektedir. Filmin genelinde küfür ve el hareketleri fazlaca kullanılmaktadır.

Murat ilk gününde, bundan sonra kanalda kaliteli işler ve kaliteli haber yapılacağı üzerine çalışanlar ile konuşmaktadır. Murat yine ilk gün, kanalın batmak üzere olduğunu, borçların ödenmezse patronun kızı Alara ile kendisinin hapse gireceğini öğrenmektedir. Ancak eğer reytingler yükselirse, kanalı bir Arap şirket satın alacaktır. Murat çalışanlarla tekrar konuşma yapmakta ve "Dediklerimi boş verin. İçi bomboş yayınlar yapacağız. Reytingleri coşturacağız” demektedir.

Şirketi satın almayı düşünen Arap müşteri ile Alara ve Murat görüşmektedir. Saç ektiren Arap müşteri Türkçe konuşmasına rağmen, yanındaki tercüman küfürlü çeviriler yapmaktadır. Toplantı sırasında Murat, "Bundan sonra öyle bomboş şeyler yapacağız ki başlıklar mükemmel ama içi bomboş olacak" demekte ve esasında bu esnada televizyondaki güncel gündüz kuşağı programları ile dalga geçmektedir.

Eski sevgili Ceren, Murat'ı tebrik etmek için pasta ile ziyarete gelmektedir, ancak pastaya antidepresan koydurmuştur. Pastadan yiyen Murat kanalda "Arayan Bulur" isimli, kaybolan insanları bulan bir program sunmak için canlı yayına çıkmaktadır. Murat ile birlikte ekip de pastadan yemiștir. Antidepresının etkisi ile Murat ve ekip canlı yayında saçma sapan şeyler yapmaktadırlar. Pastadan seyirciye de ikram edilmekte ve seyirci de önce oynamaya, sonra slogan atmaya başlamaktadır.

Reytinglerin daha da artması gerektiğini düşünen Murat müzik yarışması yapmaya karar vermektedir. Ceren'in oyunu ile mafya tarafından esir alınan Murat ve ekibi, dayak yemektedirler. Alara'nın yardımı ile kurtulduktan sonra, Murat, Ceren ile görüşmekte ve onu sevmediğini söylemektedir. Ceren de anlayışla karşılayıp, mekândan ayrılmaktadır.

Murat, Alara'ya âşılk olmuştur ve canlı yayında aşkını ilan etmektedir. Murat aşkını ilan ettiği müzik yarışmasında şarkı söylerken, Alara stüdyoyu terk etmektedir. $\mathrm{Bu}$ arada reytinglerde ciddi yükseliş olmuştur. Arap şirket kanalı satın almakta, fakat ödemeyi patron Kudret'e yaptıklarını söylemektedirler.

Murat'ın telefonu çalmakta ve Kudret aramaktadır. Kudret “... 0 kızın adı Alara değil, Naciye. Benim kızım değil oyuncu. Ama iyi oynadı parasını hak etti... Demek kanalı sana bıraktığımı zannedip, olmayan borcumu ödedin. Ama sayende zengin oldum" demekte ve telefonu kapatmaktadır.

Murat eve dönmekte ve evde Alara, gerçek adı ile Naciye'yi görmektedir. Naciye, Murat'ın borçlarını Kudret’ten aldığı para ile ödemiştir. Murat önce tepki göstermekte, fakat hemen ardından sevgili olmaktadırlar. Murat "Sanırım bu hikâye mutlu sonla bitti" demekte ve film bitmektedir.

Film birçok anlamda başarısızdır. Karakterler, konunun zayıflığı, küfür ve el kol hareketleri ile komik olma çabası, filmin kalitesini düşürmektedir. Nitelik olarak çok düşük olan film, televizyon, televizyondaki programlar ve kötü programların reyting alması ile sık sık dalga geçmektedir. Burada haklılık payı olsa da, filmin ortaya koyduğu nitelik, eleştirdikleri programlardan çok daha kötüdür. Sadece televizyon ile değil psikologlar ile de dalga geçilmektedir. Şişme bebekle psikolog tehdit edilmekte, ancak bebeğin zaten 
terapi odasında, daha açık bir deyişle gizli bir yerde olmadı̆̆ı ise göz ardı edilmektedir. Şeyma Subaşı göndermesini yapan karakterin de telefona bağımlı olması dikkat çeken bir diğer noktadır.

Cemaati oyalamak adına cenaze başında muhabbet, hiç hakkını helal etmeyen yok mu gibi sorular ya da tekrar tekrar kıldırılan cenaze namazı ise filmin, değerleri, değer aşımına uğratmasının en net örneklerindendir. Ayrıca Arap karakterinin saç ektirmiş olarak işlenmesi, Türkçe konuşan Arap müşteriyi tercümanın bol küfürlü çevirileri, filmde muhtemelen gülmesi beklenen, ancak filmin son derece bayağı ve niteliksiz olan içeriklerindendir. Ceren karakterinin getirdiği küçük pastadan neredeyse tüm kanal çalışanlarının ve hatta canı yayın programı seyircisinin bile yemesi, filmdeki mantıksız sahnelerdendir. Filmin başından itibaren birçok oyun oynayan Ceren'in, Murat'ın "Seni sevmiyorum" itirafından sonra, anlayış gösterip gitmesi de yine mantıksız olan sahnelerdendir.

Yalanlar, aksilikler, bunların arasında aşkın ortaya çıkması üzerine kurulu olan film özünde hiçbir şey anlatmamaktadır. Hiçbir değeri ya da hiçbir amacı, mesajı olmayan filmin tek amacı eğlendirmektir. $\mathrm{Bu}$ bağlamda filmin mantıksızlığın beslenmesi, ideolojisizlik, amaçsızlık, değersizlik, ahlaksal çöküntü, eğlence odaklı olması, bayağılık ve komedi parametreleriyle nihilizmi ortaya koyduğu söylenebilir. Buna ek olarak simülasyon evreninde -mış gibi yapan oyuncularla, orijinali olmayan bir kopya olan sinema filmi üretildiğinden, ayrıca derinliğin olmamasından, boşluk ve anlamsızlığın olmasından dolayı saydam/postmodern nihilizmden de bahsedilebilmektedir.

\section{Sonuç}

Nietzsche nihilizmin gelişini haber vermekte, bunun kaçınılmaz olduğunu da eklemektedir. Değer aşımı anlamına da gelen nihilizmin bir yazgı olduğunu ifade eden Nietzsche, bunun bir felaket olduğunu belirtmektedir. Değer ve amaç yokluğu, hiçlik istenci ya da yanılsama felsefesi gibi tanımlamaları olan nihilizm, Nietzsche tarafından orijinal ve Avrupa nihilizmi olarak ikiye ayrılmaktadır. Ayrıca aktif ve pasif nihilizm diye de ayrılmakta ve saldırmayan, yorgun taraf pasif nihilizm olarak adlandırılırken, yıkıcı olan ise aktif nihilizm olarak nitelendirilmektedir.

Baudrillard bu tanımlamalardan farklı olarak saydam nihilizmi ortaya atmakta ve bu nihilizm, Weller tarafından postmodern nihilizm diye de isimlendirilmektedir. İkisinin de bu nihilizm türüyle ortaya koyduğu, mutlak gerçekliğin reddedilmesi ve orijinali olmayan kopyaların olmasıdır. Bu bağlamda Baudrillard'ın simülasyon ve hipergerçeklik kavramları öne çıkmaktadır.

Tüm bunların yanı sıra nihilizm ahlaki, epistemolojik, politik, kozmik ve varoluşsal olarak da beşe ayrılmaktadır: Otoriteleri reddeden politik nihilizm, hakikati odak noktasına olan epistemolojik nihilizm, ahlaki merkezine olan ahlaki nihilizm, kozmosun anlamsızlığına dikkat çeken kozmik nihilizm ve her şeyin boşuna olduğunu düşünen varoluşsal nihilizm.

Medya ele alındığında ise medyanın rollerinin eğlenceye dönüştüğü ve bunun da medya nihilizmi olduğu iddia edilmektedir. Daha açık bir deyişle, medyanın eğlenceyi odaklı hali, kriz ve başarısızlık söylemi yaratması, olayları abartması, yeniden birleștirmesi, mantıksızlığı beslemesi, hiçbir şey ile ilgili olmayan şovlar ortaya koyması ve umut, kaygı yoksunluğu, aldırmazlık gibi varoluşsal sorunlar yaratan metinler üretmesi medyadaki nihilizmdir. Buna ek olarak internetin de nihilist olduğu ifade edilmektedir. Çünkü internet, bireylerin istedikleri anlamı yaratabilecekleri bir mecradır. 
İçerikleri kültür endüstrisi tarafından belirlendiği için medya metinlerinin içeriği boşaltılmakta, hakikat önemsizleşmekte ve medyayla yeni anlamlar sunulmaktadır. Ortaya konan bu yeni anlamlar, popüler kültüre hizmet etmekle birlikte, izleyicileri tektipleştirerek, ruhsuzlaştırmaktadır. Hakikatin önemsizleşmesine ek olarak, medyanın sürü vizyonu empoze eden yapısı nihilizme götürmektedir.

Medyanın ortaya koyduğu nihilizmi anlamlandırabilmek adına, tüm medyadan birer örnek alınmış ve toplamda altı medya metni incelenmiștir. Bunlar bir gazete haberi, bir televizyon haberi, bir sosyal medya paylaşımı, bir televizyon gündüz kuşağı programı, televizyon prime time yayını içerisinden bir dizi ve bir sinema filmi ele alınmıştır. Amaçsal örnekleme metoduyla incelenen medya metinleri için söylem analizi yöntemi kullanılmıştır. Bu bağlamda Yeni Akit gazetesi, Fox Tv ile A Haber, sosyal medya, Müge Anlı ile Tatlı Sert programı, Arka Sokaklar dizisi ve Borç Harç sinema filmi incelenmiştir.

Çalışmada ortaya çıkan sonuçlar şu şekildedir: Gazete haberinde epistemolojik nihilizm, nihilizm ve politik nihilizm vardır. Televizyon haberinde epistemolojik nihilizm, nihilizm ve politik nihilizm, sosyal medya paylaşımında epistemolojik nihilizm, nihilizm ve politik nihilizm; gündüz kuşağı programında nihilizm, varoluşsal nihilizm ve epistemolojik nihilizm söz konusudur. Dizide nihilizm, varoluşsal nihilizm ve saydam/postmodern nihilizm varken, sinema filminde nihilizm ve saydam/postmodern nihilizm vardır.

Gazete ile televizyon haberinde, haber kaynağı olarak başvurulan sosyal medyada ve reality show iddiasındaki televizyon programında epistemolojik nihilizmin çıkması dikkat çekici bir noktadır. Çünkü bilgi alma ihtiyacının karşılandığı gazete ya da televizyon haberleri veya sosyal medyayla, hayata dair gerçek olayların ele alındığı iddiasındaki televizyon programlarının epistemolojik nihilistik önermeler taşıması, sundukları gerçeklikler ve verdikleri bilgilerin doğruluğuyla ilgili soru işareti bırakmaktadır. Aynı şekilde gündemden haberdar olmak için başvurulan gazete haberi, televizyon haberi ve sosyal medyanın politik nihilist tavrının olduğu, başka bir deyişle, kendi ideolojileri doğrultusunda haberleri veren ve bu bağlamda post-truth söylemler dahi üreten bu mecraların siyasi amaç doğrultusunda hareket ettikleri ortaya çıkmaktadır.

Varoluşsal problemlere odaklanan, farklı bir ifadeyle umutsuz olma, umursamama, yabancılaşma, duyarsızlașma, keder, korku gibi duyguları odak noktasına alan varoluşsal nihilizm, televizyon şovunda ve dizide görülmektedir. Bu perspektifle, rahatlamak adına izlenen bu metinlerin esasında varoluşsal nihilizme götürdügünü ulaşılan sonuçlar içerisindedir. Yine rahatlamak ve günün stresinden arınmak için izlenilen dizi ve sinema filmlerinin saydam/postmodern nihilist taraflarının olduğu söylenebilmektedir. Son olarak da bütün medya metinlerinde farklı parametreler nedeniyle de olsa nihilistik önermeler taşıdığı sonucuna ulaşılmaktadır.

Bu noktadan hareketle, özünde amaç yoksunluğu ve hiçlik istenci gibi unsurlar barındıran nihilizmin ve nihilizmin türlerinin, medyanın tüm mecralarında söz konusu olduğu görülmektedir. $\mathrm{Bu}$ da beraberinde değersizlik, amaçsızlık, ahlaksal çöküntü, eğlence odaklı olma, sürü vizyonu, olayı abartma, post-truth söylemler, sansasyonellik, hakikatin önemsizleşmesi, pesimizm, yabancılaşma, duyarsızlık, umursamazlık, derinliğin olmaması, boşluk ve anlamsızlığın olması, umudunu kaybetme, yönünü kaybetme ve siyasi bir amaç ile hareket etme gibi sonuçları getirmektedir. Tüm bu sonuçlar, medyanın tüm mecralarıyla yayılmakta ve izleyiciyi nihilizme sürüklemektedir. 
Günün stresinden kurtulmak, rahatlamak, kafasını dağıtmak ya da gündemden haberdar olmak adına medyaya bașvuran bireyler, medyanın bu nihilistik önermelerine maruz kalarak, kendilerini nihilizmin içerisinde bulmaktadırlar. Yalana duyarsızlaşma, çevresinde olup bitenleri umursamama, ahlaksal çöküntü içinde olma, değerleri reddetme hatta değerlerin farkında olmama gibi nihilistik sorunlar ile karşı karşıya kalan bireyler, özünü kaybetmektedirler. Bunun sonucunda alternatif bir yaşam ve alternatif bir kimlik imkânı sunan, ancak esasında kendilerine ait olmayan o kimliği yaşamak adına sosyal medyaya başvuran insanlar, kendilerine ve çevrelerine yabancılaşarak varoluşsal nihilizm ile karşı karşıya kalmaktadırlar.

Medyanın eğlence endüstrisine hizmet eden tavrı, onu, değerleri baştan göz ardı ettiği ve amaçsız, ideolojisiz kıldığı için nihilistik yapmaktadır. Ancak üretilen çeşitli medya metinleriyle bu durum daha da desteklenmektedir. Bütün metinlerini eğlence olarak veren medya, tarafsız bir şekilde bilgilendirme, eğitme gibi işlevlerini tamamen yok saymaktadır. Bu doğrultuda da medya, eğlenceyi merkeze alan popüler metinler üreterek, izleyicilere nihilizmi ve nihilizmin çeşitlerini empoze ederek, kendisine tüm değer ve amaçlarından arınmış, umudunu, yönünü kaybetmiş, umursamayan, duyarsız izleyici kitleleri oluşturarak, hem her türlü yönlendirmeyi rahatça yapabilmekte hem de ürettiği bütün boş ve anlamsız içeriklerin sorgulanmadan tüketilmesini sağlamaktadır. Kendisine verileni alan Nietzsche'nin tabiri ile "sürü insanları" da nihilizmi yaşamaktadır.

\section{Notlar}

1 Post-truth: Nesnel olguların, kamuoyu oluşturmada, duygulardan ve kişisel inançlardan daha az etkili olması durumudur. Hakikatin önemsizleşmesi bağlamında, temel nokta kitlelere yalan söylemek değil, onları nesnel veriler kullanmadan, duygularına çağrılar yaparak, doğru ya da yanlış birtakım şeylere inandırmaktır. Bu kavram, hakikate karşı doğrudan bir girişim değil, hakikati önemsemeyen bir girişimdir ve hedef kitlesi, rasyonel düşünmekte zorluk çeken geniş halk kitleleridir (Alpay, 2018, s. 29).

\section{Kaynakça}

Alpay, Y. (2018). Yalanın Siyaseti. İstanbul: Destek Yayınları.

Baudrillard, J. (2011). Simülakrlar ve Simülasyon. (O. Adanır, Çev.) Ankara: Doğu Batı Yayınları.

Baurdillard, J. (1991). Sessiz Yığınların Gölgesinde. (O. Adanır, Çev.) İstanbul: Ayrıntı Yayınları.

Crosby, D. A. (1998). The Specter of Absurd: Sources and Criticisms of Modern Nihilism. New York: State University of New York Press.

Devran, Y., \& Özcan, Ö. F. (2019). Dil. Nihilizm ve Televizyon. Online Academic Journal of Information Technology, 10(39), 181-196.

Diken, B. (2011). Nihilizm. (A. Onacak, Çev.) İstanbul: Ayrıntı Yayınları.

Gülsoy, D. (2005). Chomsky. N. Rigel, G. Batuş, G. Yücedoğan, \& B. Çoban içinde, Kadife Karanlık (s. 139-192). İstanbul: Su Yayınevi.

Güngör, N. (2018). İletişim-Kuramlar, Yaklaşımlar. Ankara: Siyasal Kitapevi.

Hibbs, T. S. (2012). Shows About Nothing: Nihilism in Popüler Culture. Texas: Baylor University Press.

Kaya, R. (1999). Medya, Toplum, Siyaset. K. Alemdar içinde, Medya Gücü ve Demokratik Kurumlar (s. 23-32). İstanbul: Alfa Yayıncılı. 
Kellner, D. (2013). Medya Gösterisi. (Z. S. Doğruer, Çev.) İstanbul: Açılım Kitap.

Keyes, R. (2017). Hakikat Sonrası Çağ-Günümüzün Dünyasında Yalancılık ve Aldatma. (D. Özçetin, Çev.) İzmir: Tudem Yayın Grubu.

Lee, J. R. (tarih yok). Nihilism and the Internet Age. 04 22, 2019 tarihinde http:// anamnesisjournal.com/2015/10/nihilism-and-the-internet-age/ adresinden alındı

Lundby, K., \& Ronning, H. (2014). Medya-Kültür-İletișim: Medya Kültürü Aracıllğıyla Modernliğin Yorumlanışı. S. İrvan içinde, Medya Kültür Sİyaset (s. 13-29). Ankara: Pharmakon Yayınevi.

Mengü, M. (2006). Friedrich Nietzsche'nin “Tanrı Öldü” Sözü ve Bunun Modern Felsefi Düşünce İçinde Kapladığı Yer. İzmir: Ege Üniversitesi Sosyal Bilimler Enstitüsü.

Nietzsche, F. (2000). Deccal-Hristiyanlığa Lanet. (O. Aruoba, Çev.) Hil Yayınları: İstanbul.

Nietzsche, F. (2001). İyinin ve Kötünün Ötesinde. (A. İmam, Çev.) İstanbul: Yorum Yayınevi.

Nietzsche, F. (2010). Güç İstenci. (N. Epçeli, Çev.) İstanbul: Say Yayınları.

Özçınar, Ş. (2002). Albert Camusınün Başkaldırı Felsefesinde «Varoluşçuluk» ve «Nihilizm». Felsefelogos, 3(2), 79-98.

Pritchard, R. S. (2010). Confronting Media Nihilism: How Transparency Builds Meaning During Crises. Public Relations Journal, 4(1).

Safa, P. (2005). Nihilizm Devrinde Miyiz? Cogito Dergisi-Nietzsche: Kayıp Bir Kita, 284-285.

Stevenson, N. (2008). Medya Kültürleri-Sosyal Teori ve Kitle İletişimi. (G. Orhan, \& B. Aksoy, Çev.) Ankara: Ütopya Yayınevi. 


\title{
Media and Nihism: Turkish Media Example
}

\author{
Pınar Basmacı (Res. Asst.)
}

\section{Extended Abstract}

Notifying the arrival of nihilism, Nietzsche says that this will be a disaster, making definitions of nihilism, such as the will to nothingness and the philosophy of illusion. Saying that the experience of nihilism is a fate, Nietzsche divides nihilism both actively and passively. Baudrillard, on the other hand, states that transparent nihilism is replaced by nihilism in the postmodern process, and this type of nihilism is described by Weller as postmodern nihilism. In addition, political, moral, epistemological, cosmic and existential types of nihilism are also mentioned.

Nihilism, which shows itself in many areas, also reveals its presence in the media. However, in the media, there are definitions of nihilism such as discourse of crisis and failure, exaggeration of events, grief and fear. In other words, the media produces nihilistic propositions with its power to create and direct meaning and disseminates them with media texts. However, at this point, the definitions of nihilism different from the classical definitions of nihilism are introduced. In this perspective, a table is presented in which the types of nihilism and its parameters are presented. In other words, for each type of nihilism, parameters have been determined in the context of the media, and when one or more of those parameters are seen, it is claimed that the type of nihilism in question.

The results of the study are as follows: There are epistemological nihilism, nihilism and political nihilism in the newspaper article. Epistemological nihilism, nihilism and political nihilism in television news, epistemological nihilism, nihilism and political nihilism in social media sharing; nihilism, existential nihilism, and epistemological nihilism are involved in the daytime generation program. While the series has nihilism, existential nihilism, and transparent / postmodern nihilism, there is nihilism and transparent / postmodern nihilism in the motion picture.

It is noteworthy that epistemological nihilism appeared in the newspaper news with the newspaper, in the social media used as a news source and in the television program claiming the reality show. Because the television programs that claim the need to receive information, or television news or social media and real events related to life are addressed, the fact that television programs have epistemological nihilistic features leaves a question mark about the reality they offer and the accuracy of the information they provide. Likewise, it is revealed that these media, which are used to be aware of the agenda, have political news, television news and political nihilist attitudes, in other words, that give news in line with their own ideologies and produce post-truth discourses in this context, act in line with the political purpose.

Existential nihilism focusing on existential problems, in other words, feeling hopeless, disregarding, alienation, desensitization, grief, fear, is seen in the television show and series. From this perspective, it is within the conclusions reached that these texts that are watched for relaxation lead to existential nihilism. Again, it can be said that the series and cinema films that are watched to relax and relieve the stress of the day have transparent / postmodern nihilist sides. Finally, it is concluded that all media texts carry nihilistic propositions, albeit due to different parameters. 
From this point of view, it is seen that the types of nihilism and nihilism, which have essentially elements such as lack of purpose and desire for nothingness, exist in all media of the media. This is accompanied by worthlessness, aimlessness, moral collapse, entertainment-oriented, herd vision, exaggeration, post-truth rhetoric, sensationality, insignificance of truth, pessimism, alienation, insensitivity, indifference, lack of depth, emptiness and meaninglessness, loss of hope, direction it has consequences such as losing and acting with a political purpose. All these results are spreading with all media of the media and dragging the audience to nihilism.

Individuals who apply to the media in order to get rid of the stress of the day, relax, distract or be aware of the agenda, find themselves in nihilism by being exposed to these nihilistic statements of the media. Individuals who are faced with nihilistic problems such as desensitization to lie, ignoring what is happening around them, being in moral collapse, rejecting values, or not being aware of values lose their essence. As a result, people who offer an alternative life and an alternative identity, but who use social media in order to live that identity that is not their own, are faced with existential nihilism by alienating themselves and their environment.

The attitude of the media serving the entertainment industry makes it nihilistic because it ignores the values from the beginning and makes it aimless and ideological. However, this situation is further supported by various media texts produced. The media, which gives all its texts as entertainment, completely ignores its functions such as impartially informing and educating. In this direction, by producing popular texts centered on media entertainment, imposing nihilism and nihilism on the audience, creating all audiences that are free from all their values and goals, have lost their hopes, directions, do not care, create insensitive audience masses, they can both make all kinds of orientation easily, It ensures that meaningless content is consumed without being questioned. Nietzsche, who received what was given to him, also experiences "herd people" nihilism.

Keywords: Radio Television and Cinema, Nihilism, Types Of Nihilism, Nietzsche and Media. 